\title{
Mitogen-Activated Protein Kinase Kinase Inhibitor
}

National Cancer Institute

\section{Source}

National Cancer Institute. Mitogen-Activated Protein Kinase Kinase Inhibitor. NCI

Thesaurus. Code C69145.

Any substance that inhibits mitogen-activated protein kinase kinase (MEK), an enzyme

that catalyzes the addition of a phosphate group to a mitogen-activated protein kinase.

Inhibition of mitogen-activated protein kinase kinase results in the inhibition of cell proliferation. 